\title{
PROBLEMATIKA PENEGAKAN HUKUM DAN NAWACITA JOKOWI-JK DALAM PERSPEKTIF HUKUM TATA NEGARA DI INDONESIA
}

\author{
Sugianto, \\ FSEI IAIN Syekh Nurjati Cirebon \\ Email : sugiantoaphi@gmail.com
}

\begin{abstract}
"Nawacita" and Constitutional Law needs to be a legal approach to make improvements to the legal system, in order to encourage enforcement of the law with justice, then at least have to involve three pillars consisting of: (1) the substantive law (legal substance), which include legislative reform; (2) legal structure (law structure), including human resources law-enforcement officers (human resource), entered in it anyway coordination among law enforcement officers; and (3) the legal culture (legal culture), both culture and public law enforcement officers or citizens in general. Then, constitutional law and can be answered correctly, can be practiced within their Constitutional Act and may be unenforceable government in running the government. The key factor to keep in mind, eliminating egosektoral government agencies. Do not stop until the Act, a similar effort was also made to the laws which are in the executive area, such as government regulations, a presidential decree and ministerial regulation
\end{abstract}

Key word : Nawacita, legislation and law enforcement

\section{PENDAHULUAN}

\subsection{Latar Belakang}

Awal mula reformasi, sesungguhnya telah dilakukan banyak pemetaan dan analisis, untuk menyelematkan "hukum"sebagai salah satu pilar utama negara ini. Akan tetapi pada praktiknya, hingga saat ini belum menunjukkan perbaikan yang komprehensif dan holistik. Hal itu kemungkinan terjadi karena dalam mendorong reformasi hukum, para pihak yang terlibat, lebih banyak menggunakan pendekatan yang sifatnya taktis-tactical reformasi. Reformasi hanya dilakukan dengan memperbaiki atau menambal kekurangan di sana-sini, tanpa membuat suatu penyelidikan dan formulasi yang menyeluruh dan seksama, dan membentuk sebuah desain besar pembaruan, perbaikannya seringkali bersifat adhoc atau tambal sulam.

Kita masuk pada pertanyaan mendasar yaitu; Apa itu "Nawa" "Cita"? atau "Nawacita" itu seperti apa definisinya? Lazimnya, Ia adalah istilah umum 
yang diserap dari bahasa Sanskerta, nawa (sembilan) dan cita (harapan, agenda, keinginan).

Dalam konteks perpolitikan Indonesia menjelang Pemilu Presiden 2014, istilah ini merujuk kepada visi-misi yang dipakai oleh pasangan calon presiden dan calon wakil presiden Joko Widodo dan Jusuf Kalla berisi agenda pemerintahan pasangan itu. ${ }^{116}$ Dalam visi-misi tersebut dipaparkan sembilan agenda pokok untuk melanjutkan semangat perjuangan dan cita-cita Soekarno yang dikenal dengan istilah Trisakti, yakni berdaulat secara politik, mandiri dalam ekonomi, dan berkepribadian dalam kebudayaan.

Permasalahan Penelitian ini saya melihat dari Nawa Cita Jokowi -JK sampai sejauh mana Implementasi terhadap Program Pmerintah saat ini yang merupakan Program Unggulan dibawah kepemimpinan Presiden Jokowi- JK, yang penulis kembangkan khususnya dari Program Nawa Cita tersebut yaitu :

1. Menghadirkan kembali negara untuk melindungi segenap bangsa dan memberikan rasa aman pada seluruh warga negara, melalui politik luar negeri bebas aktif, keamanan nasional yang terpercaya dan pembangunan pertahanan negara Tri Matra terpadu yang dilandasi kepentingan nasional dan memperkuat jati diri sebagai negara maritim.

2. Membuat pemerintah tidak absen dengan membangun tata kelola pemerintahan yang bersih, efektif, demokratis, dan terpercaya, dengan memberikan prioritas pada upaya memulihkan kepercayaan publik pada institusi-institusi demokrasi dengan melanjutkan konsolidasi demokrasi melalui reformasi sistem kepartaian, pemilu, dan lembaga perwakilan.

3. Membangun Indonesia dari pinggiran dengan memperkuat daerah-daerah dan desa dalam kerangka negara kesatuan.

4. Menolak negara lemah dengan melakukan reformasi sistem dan penegakan hukum yang bebas korupsi, bermartabat, dan terpercaya.

5. Meningkatkan kualitas hidup manusia Indonesia melalui peningkatan kualitas pendidikan dan pelatihan dengan program "Indonesia Pintar"; serta peningkatan kesejahteraan masyarakat dengan program "Indonesia Kerja" dan "Indonesia Sejahtera" dengan mendorong land reform dan program kepemilikan tanah seluas

\footnotetext{
${ }^{116}$ Kementerian Pendayagunaan Aparatur Negara Dan Reformasi Birokrasi, Revolusi Mental ASN dan UU ASN, Jakarta, 18 Mei 2016
} 
9 hektar, program rumah Kampung Deret atau rumah susun murah yang disubsidi serta jaminan sosial untuk rakyat di tahun 2019.

6. Meningkatkan produktivitas rakyat dan daya saing di pasar internasional sehingga bangsa Indonesia bisa maju dan bangkit bersama bangsa-bangsa Asia lainnya.

7. Mewujudkan kemandirian ekonomi dengan menggerakkan sektor-sektor strategis ekonomi domestik.

8. Melakukan revolusi karakter bangsa melalui kebijakan penataan kembali kurikulum pendidikan nasional dengan mengedepankan aspek pendidikan kewarganegaraan, yang menempatkan secara proporsional aspek pendidikan, seperti pengajaran sejarah pembentukan bangsa, nilai-nilai patriotisme dan cinta Tanah Air, semangat bela negara dan budi pekerti di dalam kurikulum pendidikan Indonesia.

9. Memperteguh kebhinnekaan dan memperkuat restorasi sosial Indonesia melalui kebijakan memperkuat pendidikan kebhinnekaan dan menciptakan ruang-ruang dialog antarwarga.

\subsection{Identifikasi Masalah}

1. Bagamana Pemahaman Program Nawa cita dari Presiden Jokowi-JK ini terhadap pentingnya mewujudkan dalam pembangunan masyarakat di Indonesia?

2. Bagaimana Penegakan Hukum di Indonesia terhadap Implementasi Reformasi Hukum pasca Reformasi di Gulirkan dan saat ini masih menjadi sebuah tantangan bagi Penegakan Hukum yang menjadi sorotan masyarakat di Indonesia?

3. Bagaimana mengatasi Problem tersebut yang mengedepankan Nawacita dan Penegakan Hukum di Indonesia dengan tujuan mewujudkan dapat dirasakan oleh masyarakat?

\subsection{Tujuan Penelitian}

1. Pentingnya mengkaji terhadap Pemahaman Program Nawa cita dari Presiden Jokowi-JK ini dalam mewujudkan pembangunan masyarakat di Indonesia .

2. Mengkaji kembali Penegakan Hukum di Indonesia sesuai dengan Implementasi Reformasi Hukum pasca Reformasi di Gulirkan masih adanya kendala sesuai Fakta lapangan dan saat ini masih menjadi sebuah tantangan bagi Penegakan Hukum yang menjadi sorotan masyarakat di Indonesia 
3. Pentingnya merekontruksi untuk mengatasi Problem tersebut dengan mengedepankan Nawacita dan Penegakan Hukum di Indonesia .

\section{METODE DAN PENDEKATAN}

Spesifikasi penelitian ini adalah deskriptif analitis, yaitu penelitian yang bertujuan menggambarkan mengenai fakta-fakta disertai analisis yang akurat mengenai peraturan perundang-undangan yang berlaku dihubungkan dengan teori-teori hukum dan praktek yang berkaitan dengan pelaksanaan Nawa Cita.

Penelitian ini menggunakan metode pendekatan Yuridis Emperik, yakni penelitian yang menitikberatkan pembahasan pada data-data sekunder berupa bahan-bahan hukum, baik primer, sekunder maupun tersier, yang didukung data primer. Teknik pengumpulan data dilakukan melalui Penelitian kepustakaan dan Penelitian di lapangan. Penelitian lapangan dimaksudkan untuk mendukung analisis bahan-bahan hukum primer, sekunder, dan tersier. Teknik yang digunakan adalah melakukan wawancara terhadap informan,

Teknis Analisis data yang digunakan dalam penelitian ini adalah deskriptif analitis, yakni pemaparan dan penggambaran peraturan perundang-undangan yang didukung oleh data-data primer yang diperoleh dari studi lapangan. Pada teknik analisis ini, pertama-tama dilakukan analisis yuridis pada berbagai peraturan. Kemudian kedua, hasil-hasil studi lapangan yakni data primer dikumpulkan, dikategorikan, di klasifikasikan kemudian direduksikan kedalam atauran-aturan yang telah dianalsis tersebut. Hasil reduksi bahan hukum dengan data primer dilakukan analisis dan disimpulkan.

\section{PEMBAHASAN}

\subsection{Pemahaman Hukum Dalam Presfektif Nawacia}

Apa implementasinya Nawacita dalam pemerintahan Jokowi-JK dalam satu-dua tahun belakangan ini? Dalam satu tahun pemerintahan Jokowi-JK ada juga yang mengkritik dan tidak puas akan pemerintahan Jokowi-JK menanggapi hal tersebut kita berkaca pada apa yang sudah dikerjakan pemerintah bukan mengkritisi kondisi sekarang ini, kita menilai bagaimana kinerja pemerintah dalam satu tahun ini.

Diawal kepemimpinannya Presiden Jokowi-JK selalu menjunjung tinggi nawacita wujud dari nawacita diawali melalui gebrakan memilih menteri yang melibatkan KPK dalam menyeleksi menteri, point nawacita untuk mewujudkan kualitas hidup rakyat 
diterjemahkan dalam pemerintahan Jokowi-JK dengan merealisasikan program Kartu Sakti yakni Kartu Indonesia Sehat, Kartu Indonesia Pintar, dan Kartu keluarga Sejahtera, dibidang penegakan hukum dan hak asasi manusia presiden JokoWidodo-Jusuf Kalla juga telah mengambil tindakan tegas berupa eksekusi mati terhadap sejumlah bandar narkoba. Dilaut pemerintahan JokoWidodo-Jusuf Kall juga "ganas" menengelamkan kapal-kapal asing yang mencuri ikan. Kepuasaan masyarakat publik atas pemerintahan Jokowi-JK dibidang pendidikan dan kesehatan mencapai 60\% (Poltracking Indonesia Research).

Artinya adalah masyarakat menyambut baik atas kinerja Jokowi-JK dibidang tersebut. Tingkat kepuasaan masyarakat terhadap kinerja Jokowi mencapai 46.0\%, tingkat kepuasaan masyarakat atas kinerja wakil presiden Jusuf Kalla 42.1\%, tingkat kepuasan masyarkat terhadap kinerja menteri 36.3\% (Indo Barometer/IB; September 2015).

Data di atas ada sesuatu hal yang menarik dan mencolok apakah merupakan pencitraan berbasis data atau bagaimana? Tetapi dari sudut lain ada kepuasan indeks sosial masyarakat yang mencapai $40 \%$ lebih dalam kinerja pemerintahan Jokowi JK. Sekarang kita lihat apakah hal itu mrepresentasi dalam persoalan hukum bangsa dan hukum tata negara yang baik?

Dari sisi pemerintah mengklaim bebasis kinerja dan data mengatakan demikian; di bidang hukum, capaian selama kurun waktu 2 tahun adalah, pertama, Deregulasi Peraturan Daerah dengan mencabut 3.143 Perda-Perda bermasalah; kedua, Kinerja Kepolisian semakin membaik dengan indikator menurunnya angka kejahatan dari 373.636 pada 2015 menjadi 165.147 pada 2016 (per Juni) dan angka kecelakaan lalu lintas menurun secara signifikan baik jumlah kecelakaan maupun korban, pada 2016 turun menjadi 1.947 kasus dari sebelumnya di tahun 2015 sebanyak 2.228 kasus; ketiga, Kejaksaan Agung berhasil menyelamatkan keuangan negara sebesar Rp. 14,2 triliun selama Januari-September 2016; keempat, Program Tax Amnesty sebagai terobosan bidang hukum perpajakan hingga bulan Oktober telah berhasil meraih angka tebusan sebesar Rp 97,15 t riliun atau sebesar 60\% dari target Rp165 triliun; kelima, Penangkapan buronan koruptor yaitu Samadikun Hartono (kasus BLBI 1998) di Cina pada 14 April 2016, Totok Ary Prabowo (mantan Bupati Temanggung) di Kamboja pada 12 September 2015 dan Hartawan Aluwi (Kasus Bank Century) di Singapura pada 22 April 2016.

Sementara itu, Guru Besar Hukum Tata Negara Universitas Andalas, Saldi Isra, menilai selama dua tahun ini pemerintah Jokowi-JK belum fokus di bidang hukum. Pada 
tahun pertama, pemerintahan sibuk melakukan konsolidasi politik seperti hubungan pemerintah dengan DPR dalam peta politik pendukung dan bukan pendukung pemerintahan. Tahun kedua, pemerintah fokus pada bidang ekonomi ditandai terbitnya paket-paket kebijakan ekonomi. ${ }^{117}$

Persoalan hukum yang disasar dalam dua tahun terakhir hanya yang bersinggungan dengan kegiatan ekonomi dan investasi. "Pemerintah memangkas peraturan yang menghambat ekonomi dan investasi masuk, hanya itu yang digarap soal hukum."

Pakar hukum Tata Negara UGM, Zainal Arifin Mochtar, melihat cara Presiden Jokowi memilih kabinet menunjukan pemerintah menyerah terhadap kepentingan partai politik (parpol). Itu merupakan buah konsolidasi politik sehingga bidang hukum belum jadi fokus utama pemerintah. Dari sisi telaah ilmiah ada contoh menarik yaitu: hasil survei yang dilakukan Indonesian Legal Rountable (ILR) tahun 2015 menunjukan Indeks Negara Hukum Indonesia 2015 meningkat menjadi 5,32 dari tahun sebelumnya 5,18. Sudah beberapa tahun terakhir ILR melansir Indeks Negara Hukum Indonesia dengan berbagai indikator.

Apakah plus-minus hukum dalam rangkaian Nawacita dan Hukum Tata Negara sudah mencapai target yang selama ini digadang-gadang oleh pemerintah? Masihkah kapasitas hukum kita dalam pemerintahan sekarang tak berubah dari sistem otoritarianisme hukum? Tentu, penyelesaian secara sporadik dalam perbaikan hukum tidak dapat mengobati seluruh permasalahan hukum di periode Jokowi-JK hari ini. Dibutuhkan adanya sentuhan menyeluruh dalam perbaikannya, yakni perbaikan terhadap sistem hukum itu sendiri. Menggunakan pendekatan sistem hukum yang dikemukakan Lawrence Friedmen (1998) ${ }^{118}$, untuk melakukan perbaikan terhadap sistem hukum, guna mendorong penegakan hukum yang berkeadilan, maka setidaknya harus melibatkan tiga pilar yang terdiri dari: (1) substansi hukum (legal substance), yang di dalamnya mencakup reformasi legislasi; (2) struktur hukum (law structure), termasuk di dalamnya sumberdaya manusiaaparat penegak hukum (human resource), masuk di dalamnya pula koordinasi diantara aparat penegak hukum; dan (3) budaya hukum (legal culture), baik budaya aparat penegak hukum maupun publik atau warga negara pada umumnya.

Menjawab tantangan permasalahan di atas, pemerintahan Jokowi-JK kemudian dalam salah satu misi dari tujuh misi pemerintahannya menegaskan keinginan untuk

117 Saldi Isra, Hukum Yang Terabaikan, Kompas, 22 Juli 2016

${ }^{118}$ Lawrence M. Friedmen, American Law: An Introduction, New York: W.W. Norton, 1998 
"Mewujudkan masyarakat maju, berkeseimbangan dan demokratis berlandaskan negara hukum". Misi tersebut selanjutnya hendak diejawantahkan dengan agenda strategis melakukan reformasi sistem penegakan hukum yang bebas korupsi, bermartabat dan terpercaya, serta penghormatan HAM, dan penyelesaian secara berkeadilan kasus-kasus pelanggaran HAM masa lalu (agenda ke empat Nawacita). Agenda prioritas tersebut selanjutnya diturunkan ke dalam 42 prioritas utama yang menjadi bagian dari upaya untuk mencapai kemandirian di bidang politik. Jumlah 42 prioritas tersebut mencakup di dalamnya pembaruan sistem penegakan hukum, perlindungan kelompok marjinal, serta penghormatan, perlindungan dan penegakan hak asasi manusia. Namun demikian, dalam penyusunan dokumen ini, kami hanya akan berfokus pada 17 prioritas di dalam Nawacita, yang menjadi bagian dari agenda pembangunan hukum dan aparatur, sebagaimana dirumuskan di dalam Bab 7 Buku II RPJMN 2015-2019.

Ada beberapa sejumlah langkah yang harus dijalankan oleh pemerintah khususnya Kemenkuham tentunya, sebagaimana yang pernah disampaiakn Elsam :

1) Perlunya mengidentifikasi kesenjangan antara Nawacita dan RPJMN, baik pada tingkat strategi maupun indikator, untuk kemudian merumuskannya dalam rencana kerja pemerintah (RKP) tahunan, guna meminimalisir potensi kegagalan pencapaian visi misi;

2) Pentingnya memeriksa dan menginventarisasi rencana dan indikator yang dituangkan dalam matriks bidang pembangunan, yang menjadi tanggung jawab kelembagaan, untuk menghindari inkonsistensi dengan Nawacita dan RPJMN;

3) Perlunya membuat instrumen/alat yang bisa mengukur sejauh mana kemajuan dari setiap pelaksanaan rencana pembangunan, di dalam mendukung pencapaian; dan

4) Kebutuhan membuat penilaian (assessment) terhadap keseluruhan rencana pembangunan, dengan menggunakan pendekatan hak asasi manusia, untuk melihat sejauh mana potensi terjadinya pelanggaran HAM dalam setiap program dan agenda pembangunan.

Tabel: Sebagai refleksi data tabel komparasi Nawacita dan hukum HAM. ${ }^{119}$

\section{\begin{tabular}{l|l|l|} 
No. & Strategi Nawacita & Strategi RPJMN \\
\hline${ }^{119}$ Sebagai refleksi data tabel komparasi Nawacita dan hukum HAM
\end{tabular}}




\begin{tabular}{|c|c|c|c|}
\hline 1 & $\begin{array}{l}\text { Reformasi sistem } \\
\text { penegakan hukum }\end{array}$ & $\begin{array}{ll}\text { 1. Peningkatan kualitas } \\
\text { penegakan hukum: } \\
\text { 2. Peningkatan keterpaduan } \\
\text { dalam Sistem Peradilan } \\
\text { Pidana } \\
\text { 3. Reformasi Sistem Hukum } \\
\text { Perdata yang Mudah dan } \\
\text { Cepat } \\
\text { 4. Pengembangan SDM Aparat }\end{array}$ & $\begin{array}{l}\text { Strategi reformasi sistem penegakan } \\
\text { hukum dalam Nawacita lebih diarahkan } \\
\text { pada reformasi sistem hukum pidana, } \\
\text { sementara RPJMN melibatkan pula } \\
\text { reformasi sistem hokum perdata, serta } \\
\text { pengembangan SDM Aparat Penegak } \\
\text { Hukum dan pelayanan hukum. }\end{array}$ \\
\hline 2 & $\begin{array}{l}\text { Perlindungan anak, } \\
\text { perempuan dan } \\
\text { Kelompok masyarakat } \\
\text { marjinal }\end{array}$ & $\begin{array}{ll}\text { 1. Pelaksanaan sistem peradilan } \\
\text { pidana anak } \\
\text { 2. Penanganan } \\
\text { kekerasan terhadap } \\
\text { perempuan dan anak, melalui } \\
\text { strategi penguatan } \\
\text { mekanisme koordinasi aparat } \\
\text { penegak hukum }\end{array}$ & $\begin{array}{l}\text { Kelompok masyarakat marjinal menjadi } \\
\text { bagian yang akan mendapatkan } \\
\text { prioritas perlindungan bagi kelompok } \\
\text { rentan di Nawacita, sedangkan RPJMN } \\
\text { hanya mengakomodasi anak dan } \\
\text { perempuan. Selain itu, dalam RPJMN } \\
\text { strategi perlindungan anak dan } \\
\text { perempuan menjadi bagian dari } \\
\text { strategis peningkatan kualitas } \\
\text { penegakan hukum. }\end{array}$ \\
\hline 3 & $\begin{array}{l}\text { Penghormatan HAM } \\
\text { dan penyelesaian } \\
\text { secara berkeadilan } \\
\text { kasus-kasus } \\
\text { pelanggaran HAM } \\
\text { Masa lalu }\end{array}$ & 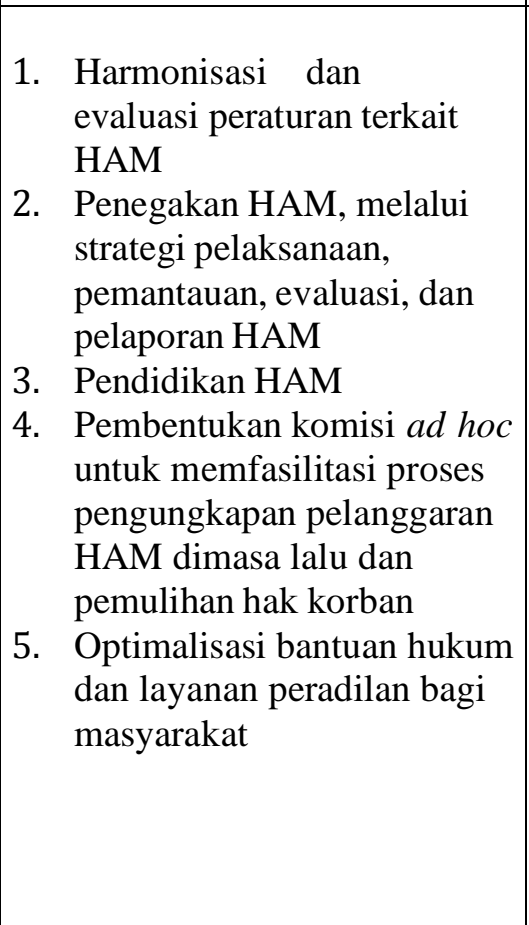 & $\begin{array}{l}\text { Dalam konteks penyelesaian } \\
\text { pelanggaran HAM masa lalu, Nawacita } \\
\text { membuka peluang penuntasan } \\
\text { dengan semua mekanisme (pengadilan, } \\
\text { komisi pengungkapan kebenaran, dan } \\
\text { pemulihan korban), sementara dalam } \\
\text { RPJMN hanya membuka peluang bagi } \\
\text { pembentukan komite ad hoc } \\
\text { pengungkapan kebenaran dan } \\
\text { pemulihan korban. Muncul } \\
\text { inkonsistensi di dalam matrik bidang } \\
\text { pembangunan, karena justru yang } \\
\text { dibuka kemungkinan untuk menggelar } \\
\text { pengadilan. Selain itu, dalam konteks } \\
\text { pendidikan HAM, Nawacita } \\
\text { mengarahkan pengintegrasian } \\
\text { pendidikan HAM dalam kurikulum } \\
\text { pendidikan dasar dan menengah, } \\
\text { sementara RPJMN hanya menekankan } \\
\text { pendidikan HAM bagi aparat negara. }\end{array}$ \\
\hline
\end{tabular}

\subsection{Telaah Agenda Hukum}

Mari kita bandingkan posisi hukum yang mandek dan yang sedang berjalan, apakah setara dengan Rencana Kerja Pemerintah Tahun (RKP) 2016 sebagai penjabaran tahun kedua dari Rencana Pembangunan Jangka Menengah Nasional (RPJMN) 2015-2019 
yang merupakan kesinambungan upaya pembangunan yang terencana dan sistematis dan dilaksanakan masing-masing maupun seluruh komponen bangsa dengan memanfaatkan berbagai sumber daya yang tersedia secara optimal, efisien, efektif dan akuntabel dengan tujuan akhir untuk meningkatkan kualitas hidup manusia dan masyarakat secara berkelanjutan.

Sebagaimana diamanatkan dalam UU Nomor 25 Tahun 2004 Tentang Sistem Perencanaan Pembangunan Nasional, maka RKP memuat prioritas pembangunan, rancangan kerangka ekonomi makro, program-program kementerian/lembaga, lintas kementerian, kewilayahan dalam bentuk kerangka regulasi dan kerangka pendanaan yang bersifat indikatif. Di mana letak ketidak sinambungan hukumnya dengan kinerja pemerintah yang terbalut dalam lumbung nawacitanya?

Sebagai refleksi bersama bahwa apabila ditelusuri kembali masa-masa awal memerintah, Jokowi-JK tidak berhasil mendapatkan momentum untuk memulai agenda penegakan hukum. Selain dihadapkan kepada masalah manuver politik sejumlah kekuatan politik di DPR, Jokowi tidak berhasil mendapatkan figur yang diyakini sepenuhnya mampu menggerakkan agenda pembaruan hukum yang tertuang dalam Nawacita. Contoh paling konkret, Jokowi harus menanggung beban politik tak sederhana ketika terjadi kisruh pengisian jabatan kapolri yang menempatkan Irjen Budi Gunawan di pusaran prokontra. Padahal, jamak dipahami, posisi kapolri menjadi salah satu figur kunci Presiden dalam penegakan hukum.

Dus, ada pula yang mengartikan kemandekan hukum demikian; bahwa dalam pemerintahan Jokowi-JK belum ada gebrakan reformasi hukum yang kongkrit khusunya di institusi kejaksaan. Padahal, gagasan pembaruan hukum dan penegakan hukum tidak mungkin berlari kencang tanpa perubahan signifikan di internal kejaksaan. Adakah terjadi perubahan signifikan di internal kejaksaan selama era Jokowi ?. Pertanyaan sederhana, tetapi pasti jauh dari sederhana menjawabnya secara tuntas. Jika sejak semula Jokowi menggariskan arah reformasi kejaksaan, pasti jauh lebih mudah melakukan evaluasi kinerja Jaksa Agung. Sebagai institusi yang berada di bawah Presiden, misalnya, sesuai agenda prioritas penegakan hukum Nawacita poin ke-39, Jokowi seharusnya memerintahkan Kapolri dan Jaksa Agung melaksanakan lelang jabatan dalam mengisi jabatan strategis di kepolisian dan kejaksaan. Seandainya titah tertulis pembaruan hukum dalam Nawacita disampaikan secara terbuka kepada Kapolri dan Jaksa Agung, berbagai 
kalangan yang concern terhadap reformasi kepolisian dan kejaksaan memiliki alasan kuat menagihnya kepada Kapolri Tito dan Jaksa Agung Prasetyo.

Melacak untaian dalam Nawacita, agenda hukum diuraikan menjadi 11 komitmen, di antaranya membangun politik legislasi yang jelas, terbuka, dan berpihak pada pemberantasan korupsi, penegakan HAM, perlindungan lingkungan hidup, dan reformasi lembaga penegak hukum. Terkhusus pemberantasan korupsi akan dilaksanakan secara konsisten dengan memperkuat Komisi Pemberantasan Korupsi. Jokowi-Kalla juga berjanji memberantas mafia peradilan yang sejak lama menjadi penyakit kronis penegakan hukum.

Selama dua tahun memerintah, komitmen Jokowi-JK dalam melakukan reformasi legislasi belum begitu terlihat. Pembentukan UU masih berjalan lazimnya sebagaimana sebelum Jokowi-Kalla memerintah. Jikalau sekarang dipertanyakan apakah sudah dapat dibuktikan satu UU yang dilahirkan dengan politik legislasi yang berbeda dari era sebelumnya, pasti tak mudah untuk memberikan jawaban yang memuaskan. Jangankan perubahan paradigma legislasi, pencapaian UU selalu berada jauh di bawah program legislasi nasional.

Kekusutan hukum itu merupakan benang merah utama dalam Nawacita sebagaimana kita lihat pada data yang pernah disampaikan oleh ILR. Pun sama halanya kalau kita menjabarkan persoalan hukum yang melilit ambiguitas keabsahan hukum itu sendiri soal banyak produk hukum daerah yang bertentangan dengan peraturan yang lebih tinggi, samplingnya; upaya pemerintah membatalkan 3.000-an produk hukum daerah mendapat apresiasi khusus sebagian kalangan. Namun, langkah tersebut belum dibuat dalam desain penyelesaian karut-marut produk hukum secara komprehensif, terutama antara pemerintah pusat dan daerah. Keluhan daerah, tak mungkin produk hukum daerah sinkron selama produk hukum yang dihasilkan pemerintah pusat tidak sinkron. Kondisi kian rumit karena UU sektoral juga menambah belenggu bagi daerah.

Catatan penting lainnya adalah memberikan solusi yang akurat terhadap implementasi hukum sebagai berikut; menginventarisasi UU yang masih berlaku untuk ditemukan substansi yang bertentangan. Kemudian, apabila akan membahas rancangan UU, dipastikan tidak terjadi tumpang tindih dengan UU yang masih berlaku. Faktor kunci yang perlu diperhatikan, menghilangkan egosektoral antarinstansi pemerintah. Tak berhenti sampai UU, upaya yang sama juga dilakukan terhadap produk hukum yang berada di wilayah eksekutif, seperti peraturan pemerintah, peraturan presiden, dan 
peraturan menteri. Kemudian, langkah serupa dilakukan pula terhadap produk-produk hukum di daerah

\subsection{PENEGAKAN HUKUM BAGI APARATUR SIPIL NEGARA}

Menkopolhukam, Wiranto menyatakan bahwa sasaran yang ingin dicapai dari revitalisasi hukum adalah, pertama memulihkan kembali kepercayaan publik terhadap hukum nasional; kedua memberikan rasa keadilan kepada masyarakat dan ketiga adanya kepastian hukum bagi masyarakat sehingga masyarakat merasa terlindungi.

Untuk melihat keberhasilan sasaran yang disampiakan Wiranto kita harus menelaah tentang keberhasilan produk hukum yang tercapai atau terealisasi. Dari sisi hukum yang bersumber dari pihak yang pro dengan pemerintah maka persoalan "hukum" dan "keamanan" dikatakan berhasil dengan penguraian data sebagai berikut;

HUKUM

Di bidang hukum, pemerintah mencatatkan 6 capaian penting selama periode kedua pemerintahan Jokowi-JK. Capaian pertama, deregulasi peraturan daerah (perda) dimana Kementerian Dalam Negeri telah mencabut 3.143 Perda bermasalah.

Capaian kedua berupa peningkatan kinerja Kepolisian dengan indikator menurunnya angka kejahatan dari 373.636 kasus pada tahun 2015, turun menjadi 165.147 kasus pada tahun 2016 (per-Juni). Selain itu, terjadi penurunan signifikan angka kecelakaan lalu lintas baik dari jumlah kasus dan korban jiwa, yakni pada tahun 2015 mencapai 2.228 kasus dan pada tahun 2016 menurun menjadi 1.947 kasus.

Capaian ketiga, keberhasilan Kejaksaan Agung menyelamatkan keuangan negara sebesar Rp 14,2 triliun selama periode Januari hingga September 2016.

Program Tax Amnesty sebagai terobosan bidang hukum perpajakan adalah capaian penting keempat. Dalam program tax amnesty, sejak Juli hingga Oktober uang tebusan telah mencapai Rp 97,15 triliun atau sebesar 60 persen dari target $R p 165$ triliun.

Capaian kelima, berupa keberhasilan menangkap dan memulangkan buronan koruptor yakni Samadikun Hartono (kasus BLBI 1998) di Cina pada 14 April 2016, Totok Ary Prabowo (mantan Bupati Temanggung) di Kamboja pada 12 September 2015 dan Hartawan Aluwi (Kasus Bank Century) di Singapura pada 22 April 2016.

Capaian keenam, pemerintah mencanangkan reformasi hukum nasional yang dilakukan secara bertahap. Pada tahap pertama pemerintah fokus melakukan 5 program, yakni pemberantasan pungutan liar, pemberantasan penyelundupan, percepatan pengurusan SIM, STNK, SKCK dan BPKB, relokasi lembaga pemasyarakatan serta perbaikan layanan hak paten, merk dan desain. Untuk mendukung program reformasi tahap pertama ini, pemerintah membentuk satuan tugas sapu bersih pungli (Satgas Saber Pungli) melalui Perpres Nomor 87 Tahun 2016. 
KEAMANAN

Dalam bidang keamanan, pemerintah mencatat tiga capaian penting selama periode kedua pemerintahan Jokowi-JK. Pertama, pembangunan di wilayah perbatasan dengan mendirikan 7 Pos Lintas Batas Negara (PLBN) dan sarana penunjangnya.

Capaian kedua, dalam upaya pencegahan radikalisme dan terorisme di tanah air dengan tewasnya Santoso pimpinan kelompok Mujahidin Indonesia Timur (MIT) yang berbasis di Poso, Sulawesi Tengah. Pada periode ini, sebanyak polisi mengamankan 170 orang tersangka anggota kelompok teroris.

Capaian ketiga, berupa keberhasilan diplomasi luar negeri RI untuk membebaskan WNI yang disandera kelompok Abu Sayyaf di Filipina Selatan.

Data ini benar, ada enam capain hukum dan tiga capaian keamanan tetapi apakah kebenaran data tersebut di atas bisa disebut sebagai suatu keberhasilan dalam indikator kajian hukum Aparatur Sipil Negara yang selama ini masih kerap terjadi manipulasi hukum dan tumpang tindih dalam pengangkatan suatu jabatan tertentu.

Hukum dalam konteks Aparatur Sipil Negara berarti kita bicara birokrasi yang tidak lepas dari konteks hukum itu sendiri. Karl D Jackson menilai bahwa birokrasi di Indonesia adalah model bureaucratic polity di mana terjadi akumulasi kekuasaan pada negara dan menyingkirkan peran masyarakat dari ruang politik dan Pemerintahan. Richard Robinson dan King menyebut birokrasi di Indonesia sebagai bureaucratic capitalism. $^{120}$

Sedangkan kalau kita melihat pendapatnya Hans Dieter Evers melihat bahwa proses birokrasi di Indonesia berkembang model birokrasi ala Parkinson dan ala Orwel. Birokrasi ala Parkinson adalah pola dimana terjadi proses pertumbuhan jumlah personil dan pemekaran struktural dalam birokrasi secara tidak terkendali. Sedang birokrasi ala Orwel adalah pola birokratisasi sebagai proses perluasan kekuasaan Pemerintah dengan maksud mengontrol kegiatan ekonomi, politik dan sosial dengan peraturan, regulasi dan bila perlu melalui paksaan. ${ }^{121}$

Birokrasi di Indonesia tidak berkembang menjadi lebih efisien, tetapi justru sebaliknya inefisiensi, berbelit-belit dan banyak aturan formal yang tidak ditaati. Birokrasi di Indonesia ditandai pula dengan tingginya pertumbuhan pegawai dan pemekaran struktur organisasi dan menjadikan birokrasi semakin besar dan membesar.

\footnotetext{
${ }^{120}$ Afadlal (Ed.), Dinamika Birokrasi Lokal Era Otonomi Daerah, Jakarta: P2P LIPI,2003.

${ }^{121}$ Hans-Dieter Evers dan Tilman Schiel, Kelompok-Kelompok Strategis: Studi Perbandingan tentang Negara, Birokrasi, dan Pembentukan Kelas di Dunia Ketiga, Jakarta: Yayasan Obor Indonesia, 1990, hal, 228.
} 
Birokrasi juga semakin mengendalikan dan mengontrol masyarakat dalam bidang politik, ekonomi dan sosial.

Melalui pendekatan budaya birokrasi Indonesia masuk dalam kategori birokrasi patrimonial. Ciri-ciri dari birokrasi patrimonial adalah (1) para pejabat disaring atas dasar kriteria pribadi; (2) jabatan dipandang sebagai sumber kekayaan dan keuntungan; (3) para pejabat mengontrol baik fungsi politik maupun fungsi administrasi; dan (4) setiap tindakan diarahkan oleh hubungan pribadi dan politik.

Undang-Undang Republik Indonesia Nomor 5 Tahun 2014 Tentang Aparatur Sipil Negara mengatakan :

"bahwa dalam rangka pelaksanaan cita-cita bangsa dan mewujudkan tujuan negara sebagaimana tercantum dalam pembukaan Undang-Undang Dasar Negara Republik Indonesia Tahun 1945, perlu dibangun aparatur sipil negara yang memiliki integritas, profesional, netral dan bebas dari intervensi politik, bersih dari praktik korupsi, kolusi, dan nepotisme, serta mampu menyelenggarakan pelayanan publik bagi masyarakat dan mampu menjalankan peran sebagai unsur perekat persatuan dan kesatuan bangsa berdasarkan Pancasila dan UndangUndang Dasar Negara Republik Indonesia Tahun 1945; ”

Kemudian diperjelas dengan kalimat :

"bahwa pelaksanaan manajemen aparatur sipil negara belum berdasarkan pada perbandingan antara kompetensi dan kualifikasi yang diperlukan oleh jabatan dengan kompetensi dan kualifikasi yang dimiliki calon dalam rekrutmen, pengangkatan, penempatan, dan promosi pada jabatan sejalan dengan tata kelola pemerintahan yang baik."

Hal ini menunjukan bahwa profesi bagi Pegawai Negeri Sipil dan pegawai pemerintah dengan perjanjian kerja yang bekerja pada instansi pemerintah terdiri dari Pegawai Negeri Sipil dan pegawai pemerintah dengan perjanjian kerja yang diangkat oleh pejabat pembina kepegawaian dan diserahi tugas dalam suatu jabatan pemerintahan atau diserahi tugas negara lainnya dan digaji berdasarkan peraturan perundang-undangan.

Dalam hal ini penelaahan hukum tertuju pada praktik hukum yang diregulasikan oleh Kementerian Pendayagunaan Aparatur Negara dan Reformasi Birokrasi yang mempunyai tugas menyelenggarakan urusan di bidang pendayagunaan aparatur negara dan reformasi birokrasi dalam pemerintahan untuk membantu Presiden dalam 
menyelenggarakan pemerintahan Negara. ${ }^{122}$ Dalam melaksanakan tugas, Kementerian Pendayagunaan Aparatur Negara dan Reformasi Birokrasi menyelenggarakan fungsi:

1. Perumusan dan penetapan kebijakan di bidang pendayagunaan aparatur negara dan reformasi birokrasi;

2. Koordinasi dan sinkronisasi pelaksanaan kebijakan di bidang pendayagunaan aparatur negara dan reformasi birokrasi;

3. Pengelolaan barang milik/kekayaan negara yang menjadi tanggung jawab kementerian pendayagunaan aparatur negara dan reformasi birokrasi; dan

4. Pengawasan atas pelaksanaan tugas di lingkungan kementerian pendayagunaan aparatur negara dan reformasi birokrasi.

Berdasarkan pada aturan memang sudah sesui, namun dalam praktik yang kerap terjadi dalam penengakan hukum yang berbasis pada Aparatur negara kita selalu kecolongan momentum kelemahan-kelemahan yang kerap menjadi problem bersama antara lain; (1). Korupsi dan penyalahgunaan wewenang, (2) Peraturan perundangundangan tumpang tindih, (3) Kewenangan tumpang tindih, (4) Organisasi yang belum proporsional, (5) Kualitas dan kuantitas SDM Aparatur belum ideal, (6) Akuntabilitas kinerja yang belum baik, (7) Kualitas pelayanan publik masih rendah.

Permasalahan yang kerap muncul dalam penegakan UU Aparatur Sipil Negara Dalam benuk Bagan 3.1.

Mau tidak mau, suka tidak suka, karena hukum adalah pilar utamanya maka sudah tepat jika arah kebijakan tersebut harus seikat dengan reformasi birokrasi sesuai dengan RPJM 2015-2019. Apa kemudian yang mendasari secara hukum sehingga perlu dijawab dengan ketetapan yang kuat dan bisa terlaksana dengan baik dan benar. Pertama harus ada area yang dirubah dan dirombak secara menyeluruh. Kedua harus ada sasaran akuntabilitas, transparan dan tidak melanggar hukum.

\footnotetext{
${ }^{122}$ Peraturan Presiden Nomor 56 tahun 2013 tentang Perubahan ke empat atas Peraturan Presiden Nomor 24 Tahun 2010 tentang Kedudukan, Tugas, dan Fungsi Kementerian Negara serta Susunan Organisasi, Tugas, dan Fungsi Eselon I Kementerian Negara.
} 


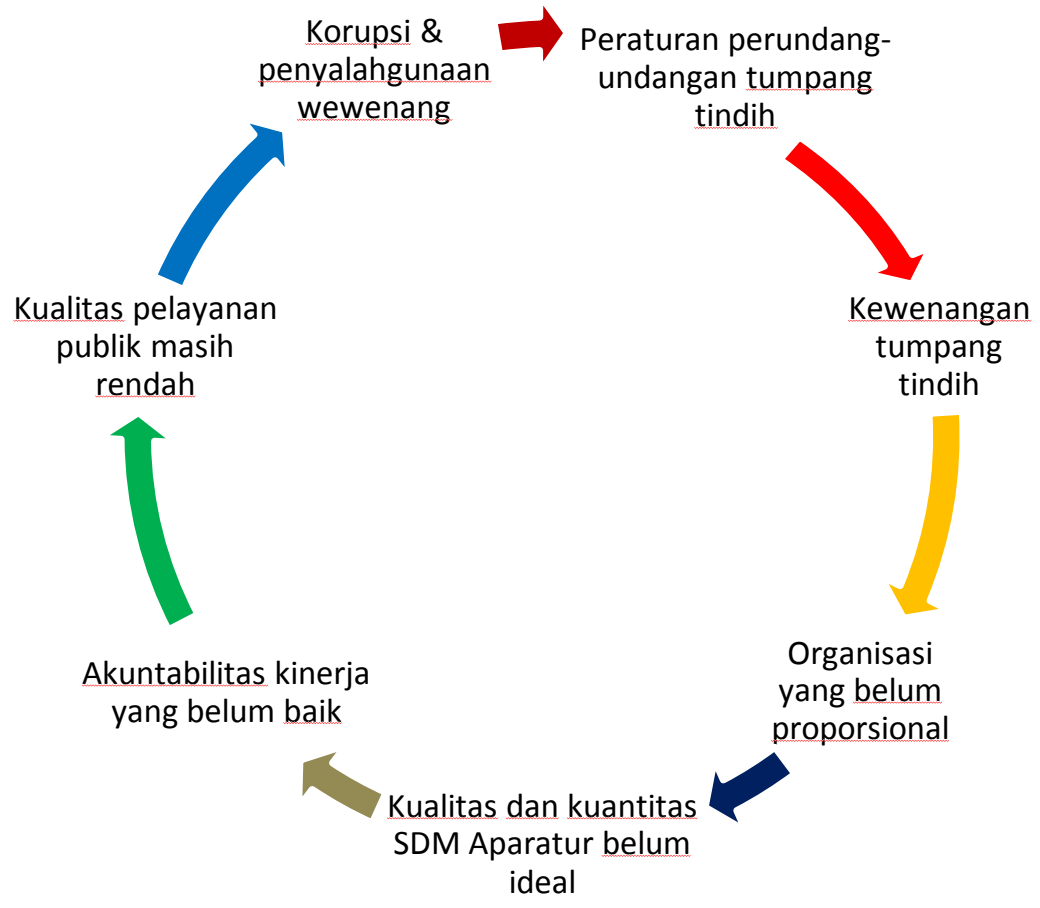

Bagan 31. Permasalahan Aparatur Sipil Negara

Area yang harus digarap anatara lain; mental aparatur, lembaga negara, tata pelaksananaan, SDM aparatur, Akuntabilitas, Pengawasan, Peraturan perundangundangan, dan peningkatan pelayanan publik. Sasaran kuatnya adalah demi terwujudnya birokrasi yang bersih, akuntabel, efektif-efisien, dan kualitas prima dalam pelayanan publik. $^{123}$

Ada poin krusial dalam hal perundangan yaitu pemberlakuan sistem merit. Undang-Undang Aparatur Sipil Negara (ASN) nomor 5 tahun 2014 yang ditandatangani 15 Januari 2014 telah merubah paradigma yang selama ini melekat pada PNS. Sebelumnya PNS terdiri dari PNS pusat, daerah dan PTT, disamping itu ada PNS TNI dan POLRI. Dengan berlakunya ASN ini hanya terdapat 2 jenis pegawai sebagai unsur aparatur negara, yaitu Pegawai Negeri Sipil Republik Indonesia (PNS) dan Pegawai Pemerintah dengan Perjanjian Kerja (PPPK). Terdapat juga perubahan batasan usia pensiun PNS dari 55 tahun menjadi 58 tahun.

Bahwa usia produktif dan tidak menjadi salah satu tolak ukur hukum dalam melaksanakan kinerja pemerintahan dan mampu jadi terobosan terbaru. Tetapi itu saja tidak cukup manakala usia jadi ukuran suatu keberhasilan kinerja dalam konteks hukum,

\footnotetext{
${ }^{123}$ Made Suwandi, Agenda Kebijakan Reformasi Pemerintahan Daerah, Badan Litbang Depdagri, Jakarta, 2001
} 
harsu seimbang dengan penguraian maslaha-masalah yang lain serta berpatokan pada road map kinerja pemerintah sejak 2015 hingga 2019.

\section{PENUTUP}

\subsection{Simpulan}

Bersdasarkan pemahaman penulis baik secara eri dan implemtasi yaitu dituangkan dalam bentuk simpulan sebvagai berikut :

1. Nawacita dalam konteks regulasi hukumnya tidak menjadi produk yang paling sempurna. Ia adalah karya manusia biasa yang bisa saja dimanfaatkan demi kepentingan politik dan agenda-agenda lainya. Terlepas dari itu, meanata hukum Aparatur Sipil Negara yang berkaitan dengan sejauh mana letak keberhasilan reformasi birokrasi, dan kesinambungan antara hukum yang terimplementasi dan hukum yang sebatas jadi "papan nama” belaka.

2. Reformasi birokrasi di bidang kepegawaian ditandai dengan diberlakukannya Undang-Undang Nomor 43 Tahun 1999 tentang Perubahan Atas Undang-Undang Pokok Kepegawaian yang merupakan perubahan dan penyempurnaan dari Undang-Undang Nomor 8 Tahun 1974. Kemudian diikuti dengan berbagai peraturan pelaksanaan, baik yang berupa Peraturan Pemerintah (PP) maupun Keputusan Presiden (Keppres), untuk menjamin terlaksananya Undang-Undang Nomor 43 Tahun 1999 ini secara baik dan terarah.

3. Merujuk pada Undang-Undang Republik Indonesia Nomor 5 Tahun 2014 Tentang Aparatur Sipil Negara; bahwa bagaimana agenda perubahan hukum Aparatur Negara Sipil yang berkaitan dengan reformasi birokrasi tidak lantas diam karena beberapa pesoalan akuntabiltas dan korupsi kepegawaian dan seterusnya. Ia sealu berjalan menata kesiapan hukum dalam mengahadapi tantangan hukum yang makin meruncing ke bawah. Tetapi harus di buktikan dulu dengan rakyat bahwa hukum dan nawacita itu benar-benar sinergi dan membuahkn hasil sesuai RPJM 2015-2019.

\subsection{Saran}

1. Pentingnya pemahaman Program Nawacita dan Penegakaan Hukum di Indonesia dapat dirasakan oleh masyarakat dan sampai saat ini Hukum seolah olah masih menjadi Gaduh pada masyarakat Indonesia, 
2. Bagi Aparatur Sipil Negara dan Aparat TNI-POLRI dalam Reformasi Indonesia ini tentunya sebagai pengayom masyarakat harus mengedepankan untuk mewujudkan rasa aman masyarakat Indonesia terhadap kondisi saat ini.

\section{DAFTAR PUSTAKA}

\section{Buku, Artikel}

Afadlal (Ed.), 2003, Dinamika Birokrasi Lokal Era Otonomi Daerah, P2P LIPI, Jakarta.

Hans-Dieter Evers dan Tilman Schiel, 1990, Kelompok-Kelompok Strategis: Studi Perbandingan tentang Negara, Birokrasi, dan Pembentukan Kelas di Dunia Ketiga, Yayasan Obor Indonesia, Jakarta.

Kementerian Pendayagunaan Aparatur Negara Dan Reformasi Birokrasi, Revolusi Mental ASN dan UU ASN, Jakarta, 18 Mei 2016.

Komang Rai Sudjaka, 2004, Wewenang Kepala Daerah dalam Pengangkatan dan Pemberhentian Pegawai Negeri Sipil untuk Jabatan Struktural, Tesis, Program Pascasarjana Fakultas Hukum Universitas Udayana, Denpasar.

Lawrence M. Friedman, 1998, American Law: An Introduction, W.W. Norton, New York.

Lili Romli, "Otonomi Daerah dan Birokrasi Lokal: Kasus Kabupaten Pandeglang" dalam Syamsuddin Haris, "Sentralisasri Baru Dalam Birokrasi Lokal:Kasus Kabupaten Bima", dalam, Afadlal,(Ed.),Dinamika Birokrasi Lokal Era Otonomi Daerah, Jakarta: P2P LIPI,2003, hal. 64.

Lili Romli, Masalah Reformasi Birokrasi, Jurnal Kebijakan dan Manajemen PNS, Vol. 2 November 2008.

Made Suwandi, 2001, Agenda Kebijakan Reformasi Pemerintahan Daerah, Badan Litbang Depdagri, Jakarta.

Saldi Isra, Hukum Yang Terabaikan, Kompas, 22 Juli 2016

Saldi Isra, Mempercepat Agenda Hukum, Kompas 21 Oktober 2016.

Sri Martini, Hj. Setiajeng Kadarsih, dan Tedi Sudrajat, 2008, Hukum Kepegawaian di Indonesia, Sinar Grafika, Jakarta.

\section{Peraturan Perundang-undangan}


Peratutan Presiden Nomor 60 Tahun 2105 Tentang Rencana Kerja Pemerintah Tahun 2016, Tema : Mempercepat Pembangunan Infrastruktur Untuk Memperkuat Fondasi Pembangunan Yang Berkualitas, hlm. 1-1

Peraturan Presiden Nomor 24 Tahun 2010 tentang Kedudukan, Tugas, dan Fungsi Kementerian Negara serta Susunan Organisasi, Tugas, dan Fungsi Eselon I Kementerian Negara

Peraturan Presiden Nomor 56 tahun 2013 tentang Perubahan ke empat atas Peraturan Presiden Nomor 24 Tahun 2010 tentang Kedudukan, Tugas, dan Fungsi Kementerian Negara serta Susunan Organisasi, Tugas, dan Fungsi Eselon I Kementerian Negara. 